and made a lumbar puncture. In January this child much improved, but cannot use right les.

A. B. aged 11 years, occupying the same room, became ill with loss of power in back, cannot sit up and cries if "bent." Temperature normal, limbs unaffected.

Case vi died in January from bronchopneumonia.

$$
\text { CASE viII (Dr. Cross). }
$$

A. J. S. aged 1 rear 8 months, Barroway Drove, near Case $r$. Mother noticed for a week previous that he fell about, and attributed this to some new boots.

On October 3lst he fell down and could not get up again. On November lst visited and found child lying on sofa. Temperature 101.4 , restless and fretful, breathing natural. Any attempt to straighten limbs caused child to cry out. Rigidity of to straighten limbs caused child to cry out. Rigidity of muscles of neck, and spine slightly arched. Bowels con rtipated. Tro dars afterwards temperature was normal and child appeared better. Left leg appeared useless. The child :radually got better, and after four weeks was able to sit up and crawl about.

Present condition: Can stand with assistance, but cannot control the left leg, which is slightly wasted. No shortening. Health otherwise good.

\section{GROUP III}

CASE IX (Dr. Wales).

S. S., aged 2: rears, Crimplesham. Taken ill November 5 th On 6 th temperature $103^{\circ}$, no definite symptoms, was thought to be a stomach attack. Seen on the 8th. Temperature $101^{\circ}$. Crying about aching in arms, difficulty in arm movements, moved legs freely. Left arm gradually became quite paralised and remained so. The acute illness lasted five days.

$$
\text { CASE } x \text {. }
$$

A. R., aged 1 rear 3 months, Crimplesham (living next door to Case IX). iIrs. R. had been backwards and forwards. Became ill about November 15th. A very indefinite illness, fretful and refuses food. Declines to be "sat up," and keeps back rigid, lies on back passively and cries if moved. On Norember 28 th all symptoms have disappeared except for weakness and rigidity in back.

REMARKs.

There had been no abnormal amount of sickness in the district, and very few cases of infantile diarrhoea.

Four of the cases lived in good farmhouses with wellto-do parents, three in good cottages, and there were only two houses in which the sanitary conditions were unsatisfactory.

Eight of the cases were in the fen, some being a good distance from the high road, and were therefore not subject to any unusual amount of dust.

There were no known cases of paralysis in animals or fowls on the various premises.

Flies and other insects were abundant, and in three of the houses there were undoubtedly a number of fleas.

With the exception of Cases III and Iv there were other cliildren in all the houses, but in only one house was there more than one case.

\section{SERUY AND VACCINE THERAPY IN CONNEXION WITH DISEASES OF THE EYE.}

The Midilemore Prize Essay, British Medical Association, 1911.

BY C. W. G. BRYAN, F.R.C.S.ENG.,

IATTY ASSISTANT IN THE DEPARTMENT FOR THERAPEUTIC INOCELATION, ST, MARY'S HOSPITAL; AND HOUSE-SURGEON, OXFORD FYE HOSPITAL. (Concluded from page 66.5.)

III.

The Sercy Treatment of Diseasles of the Ere. SERT MS, antitoxic and antibacterial, have been used very extensively in treating cases of eyc disease, and may be divided into two classes-those which have a specific action and those. which are non-specific (the so-called "paraspecitic serums").

Serum has usually been injected either into the subcutaneous tissues, the most frequently used and safest method; into muscular tissues; or into the blood stream the method by which the most rapid effect is obtained. It has also been given by mouth and by rectum. Darier concludes that serums giren by mouth immunize but exert no bactericidal effect.

Specific Serums.

1. Diphtherin Antitoxic Serum.-As in diphtheria elsewhere, so in diphtheria of the eye extremely good results lave been obtained by the use of this method of treatment. Sydney Stephenson ${ }^{1}$ has reported cases successfully treated in this way. The dose should be 2,000 to 10,000 units, and at least two doses are usually necessary. In membranous conjunctivitis due to the Klebs-Lceffler bacillus the Roux serum is valuable; Axenfeld ${ }^{2} 1$ as analysed the results obtained and reports favourably. In corneal diphtheria the serum is less effectual, and this is due to the fact that, though the serum does overcome the toxic effects of the Bacillus diphtheriae, tle severity of the corneal complications depends on the mixer nature of the infection from the presence of the ordinary organisms of suppuration, staphylococci, streptococci, pneumococci, etc.; the serum has only a non-specitic effect on these organisms. In such mixed infections Römer's antipneumococcus serum and polyvalcnt in i streptococeus serum are of use. Post-diphtherial paralysis of eye muscles: Aubineau ${ }^{24}$ reports a case of paralysis of accommodation cured by injection of antidiphtheria serum. Three relapses subsequently occurred, each of which yielded to the treatment. Four doses (10 c.cm., 20 c.cm., 30 c.cm., 60 c.cm.) were given in this case.

2. Tetanus Antitoxic Serum.--This serum, of the same nature scientifically as antidiphtheria serum, is of valuc in treating tetanus having its primary point of infection in the eye. Such cases are rare, but Ellis has had two recoreries of three cases treated. Lewis also has reported the recovery of a case. Diphtheria and tetanus are the two diseases due to organisms possessing an extracellular tcxin, and for this reason are especially suitable for the use of specific antitoxic serums. Specific serums bare been prepared and used in infections by many other organisms with varying results. Possibly the benefit obtained in some cases does not depend on the specific nature of the serum as it does in diphtheria and tetanus. As I shall mention later, in infections due to the ordinary pyogenic cocci excellent results have been obtained with non-specific serums.

3. Specific Antipncumococcus Serum.-Nany methcds of preparing antipneumococcus serum have been employed. Fornel Scholtz: finds that the serum produced by infecting an animal with one culture of pneumococcus usually has no effect in agglutinating other cultures of that organism; these experiments demonstrate the existence of different strains of pneumococci. It is impracticable in clinical medicine to prepare a serum by immunizing animals to cultures obtained from individual patients, and therefore the employment of a polyvalent serum, prepared from many strains, becomes necessary. The best known poly. valent antipnenmococcus serum was that of Römer. Römer ${ }^{4}$ has lately modified the method of preparation of his serum, and has introduced a new serum on the lines of Bail's antiaggressin-containing serum; using this new serum, he reports success in the treatment of pneumococcal ulcer's of the cornea.

4. Antirhenmatic Serum.-Rosenthal claims good results in rheumatic iritis by the use of a specific antibacterial serum prepared by immunizing animals against the Streptococcus rheumaticus. The results have not been corroborated, and Darier ${ }^{8}$ says better results are obtaincl in such cases by using Roux's serum.

5. Antistreptococcus Serum. - Polyvalent antistreptococcus serum has given occasional good results in streptococcal infections of the eye, but the results are not constant owing to the enormous number of strains of streptococcus which have been demonstrated. Recent methods of analysing the strain infecting any particular case by means of the sugar reactions may make possible the use of antiotreptococcus serum prepared with a corresponding strain. Snell ${ }^{5}$ reports a case greatly benefited by antistreptococcus serum. The patient had suffered from suppuration of the lids of the right eye for scven days, the temperature was $103^{\circ}$, delirium was marked, and the general condition grave. Streptococci were found in pure culture. Three injections, each of $10 \mathrm{c.cm}$. of polyvalent antistreptococcus serum, were given orev a period of forty-eight hours. On the following days the temperature was subnormal, delirium abated, and eventually a cure resulted. On the other hand, Lawson's found antistreptococcius serum of no us in a case of acute streptococcus infection of the cormea.

Antigonococcus Serum.-An antigonococcus serum lias been prepared by. Rogers and Torry by injecting living gonococci into the peritoneum of sheep. Knapp ${ }^{7}$ reports results of the use of this serum. He has found it of no 
value in conjunctivitis, but in treating four cases of gonococcal iritis he has had three cures, the result in the fourth case being indefinite.

Antistaphylococcus Serum.-At various times serums obtained from animals by immunizing them against staphylococci have been employed, with no results of value. As we have seen, staphylococcal infections are most favourable for the employment of vaccine.

Eye affections due to the dipiococcus of epidemic cerebrospinal meningitis are not unknown, and in these cases Flexner's serum has been found to be of value.

The results, then, of the treatment of eye diseases by specific antitoxic and antibacterial vaccines are promising but uncertain, and a method of treatment giving more constant results has been looked for. Great attention has been given to the use of non-specific (so-called "paraspecific") serums.

Non-specific Serums.-Darier ${ }^{8}$ carried out an extensire search through the columns of La Clinique Ophthalmologique, and reported his results and conclusions in a long paper; his paper largely is an exposition of the value of paraspecific as opposed to specific serum-therapy, and he shows particularly the value of the Roux serum in treating disease other than diphtheria. The following infections were inquired into: Psendo-membranous conjunctivitis, infective corneal ulcers, parenchymatous and scrofulous keratitis, iritis and irido-cyclitis, traumatic and postoperative infections. Except in the case of diphtheria and tetanus, paraspecific serum treatment has given better results than specific serums, that is, the antistreptococcal serums, the antipneumococcal serums of Römer, and the antirheunatic serum of Rosenthal.

In the majority of ocular infections the result is the same whether one employs the serum of Roux, antitetanic serum, antirheumatic serum, or Deutschmann's yeast serum. It is found that every antitoxic serum acts in two ways: in addition to its specific action on the disease against which it has been prepared, it also possesses the property of bringing to every organism invaded by any infective agents some elements of general defence, capable of neutralizing or of attenuating to a greater or lesser degree the majority of the morbid symptoms caused by the said infection.

Roux's serum has been, perhaps, most extensively used as a paraspecific serum, and very many infections of the eye have been treated thus. Alexandroff ${ }^{9}$ advises its use in $10 \mathrm{c.cm}$. doses, and as many as four doses may be necessary.

\section{Conjunctivitis.}

Excellent and permanent results have been obtained in infective conjunctivitis by Alexandroff, ${ }^{9}$ and by Darier, ${ }^{11}$ who has treated simple purulent conjunctivitis, gono. coccal conjunctivitis, and pseudo-membranous conjunctivitis. Fromaget ${ }^{10}$ reports two cases of purulent ophthalmia with false membrane due to pneumococcus cured within forty-eight hours by injections of anticliphtherial serum.

Ulceration of the Cornea.

Here also good results have been obtained. Darier, in 1903, was the first to use Roux's serum paraspecifically in a case of staphylococeus conjunctivitis with ulceration of both corneae; the ulcers disappeared with scarcely a trace of scar. Since that date the same author has reported good results with pneumococcal ${ }^{13}$ and other varieties of hypopyon vlcer. ${ }^{11}$ Monbonyran ${ }^{12}$ reports six successive cases of hypopyon ulcer cured by Roux's serum, using $10 \mathrm{cccm}$. about every three days. Alexandroff ${ }^{9}$ treated a case of serpent ulcer in a woman aged 42 . There was no lacrymal disease. Under ordinary treat: ment the condition became worse, so $10 \mathrm{c.cm}$. of Roux's serum were given, and the case improved. Two further injeations -were followed by recovery; and two years later rision was normal.

Post-operative and Traumatic Infections.

Teulières ${ }^{15}$ reports gcod results from the use of Roux's serum in infected wounds and perforations leading to irido choroiditis and traumatic cataract. Alexandroff, ${ }^{14}$ Darier, ${ }^{11}$ and other authors have used it with success in post-operative infections.

Darier" describes a modification of the nse of antidiphtheritic serum. He follows its use by that of collargol injections in gonococcal cyelitis, septic corneal ulcers, panophthalmitis and septic wounds, and claims that the results are better than those obtained by the use of Roux's serum alone. He believes the effect obtained resembles that of a specific serum, but I think we ought rather to consider it as a treatment by autoinoculation, the collargol by its toxicity producing reaction which causes anto. inoculation, by which means the patient may produce in his serum a great variety of protective substances.

\section{Exophthalmic Goitre.}

Mention must be made of Burkard's ${ }^{16}$ experiments. Using antidiphtheritic serum in four cases of exophthalmic goitre, he reports three cases relieved. The results resemble those obtained by many methods of treatment, where rest of the patient commences only at the same time as the special method of treatment, and it is rather to the rest that the relief of symptoms is due.

\section{Deutschmann's Yeast Serum.}

Deutschmann ${ }^{17}$ introduced a paraspecific serum for which excellent results have been claimed in many forms of eye disease. The serum originally was prepared by feeding rabbits on yeast in ascending doses, the serum of these rabbits being then injected into patients suffering from staphylococcus, pneumococcus, streptococcus, or other infections. Later the method of preparation underwent modification, and Deutschmann, ${ }^{18}$ in August, 1908, described before the British Medical Association two modifications of his serum, prepared from horses, for human use :

1. Deutschmann's serum, consisting of the serum of horses fed on yeast and trikresol ; this serum is obtainable in 2 c.cm. bottles.

2. Deutschmann's Serum $\mathrm{E}$, which is the active serum precipitated and redissolved. It is of double the concentration of (1), and possesses the merit of never producing serum sickness.

Dosage : In children 1 to 2 c.cm. is given as a dose. In adults $2,4,6$, or 8 c.cm. should be given two or three times weekly (occasionally more often), regulating the dose by the effect on temperature (which rises after an overdose) and clinical symptoms of the local disease.

It is given as an intramuscular injection; but, if this is for any reason impracticable, has good effect when administered per rectum.

As a curative measure Deutschmann has used his serum with good results in perforating wounds, hypopyon keratitis, post-operative infections, recurrent iritis, acute purulent irido-cyclitis, gonococcal infections, and in a case of sympathetic ophthalmia, in which, in spite of the fact that the exciting eye was not removed, a cure was obtained. Deutschmann and Neunhardt report the cure of a case of severe metastatic panophthalmitis due to endocarditis probably of gonococcal origin.

Deutschmann's results have been corroborated by many workers. Caravaria of New York has had success in septic wounds, rheumatic iritis, acuto puralent iridocyclitis, ulceration of the cornea follotwing a burn, phlyctenular pannus, and post-operative irido-cyclitis in a patient suffering from diabetes. Cases of hypopyon keratitis healed rapidly with very slight opacity remaining. Darier ${ }^{8}$ reports favourably, as does Schwalbach ${ }^{20}$ in recording a severe case of inflammatory exophthalmos cured rapidly by the use of Deutschmann's serum; two relapses occurred, but each disappeared after a further dose of serum.

Von Hippel ${ }^{21}$ has treated forty cases and gives his results. He obtained success in ulcus serpens, iritis plastica, and non-triberculous iritis serosa. On the other hand, he found it useless in serere affections of the vitreous body. In the hands of certain other workers, however, no good has resulted from the use of Dentsch mann's serum. Schmidt Rempler has been able to see no curative effect in severe hypopyon keratitis, and Napp ${ }^{24}$ of Berlin has likewise obtained no success with this treatment. 'W. Zimmermann ${ }^{23}$ iays great stress on the importance of using'Dëatschmann's serum early, and demonstrates its use in pneumococcal ulcers, iritis, and post-operative infections. He also advocates its use as a prophylactic against infection in perforating wounds and in operations on decrepit individuals, etc.

We see, then, that for a great variety of infections the use of Deutschmann's sertum is upheld by many authors, but the natare of its action is unknown. The more likely 
explanation is that of Neisser and Guerrin, who consider it a leuco-stimulant.

Non-specific antitoxic serums are, then, of great value in eye infections, and their action corresponds probably with the action of normal horse serum, the use of which was adrocated by Horder.

\section{Römer's Jequiritol Serum.}

Römer employs a serum to counteract the excessive reaction which follows the use of jequiritol for pannus. The serum may be given subcutaneously or locally into the conjunctiva; the former method is preferable. Also, to avoid the occurrence of dacryocystitis from jequiritol, the serum may be instilled into the lacrymal sac before using the drug.

$$
\text { Coley's Fluid. }
$$

Cases of sarcoma of the antrum and orbit can be benefited by Coley's fluid containing the toxins of streptococcus and Bacillus prodigiosus, and cases treated thus have been recorded by Jack, de Schweinitz, Brandoux, Coley, and Weeks.

$$
\text { Syphilis. }
$$

The relation of serum treatment to syphilis of the eye must be mentioned. No antisyphilitic serums of any clinical value have been obtained up to the present time. The Wassermann serum test and its modifications have a close relation to the general treatment of syphilis by mercury, etc., in regulating the duration of such treatment.

\section{Sympathetic Ophthalmia}

There is some promise of success in the treatment of this condition by means of serum. Santucci ${ }^{25}$ has reported some experiments on animals, as the result of which he believes that there is a cytotoxin for the organ of vision which by its appearance may cause the attack of sympathetic ophthalmia. Three series of experiments vere carried out :

1. One eye of an animal was enucleated and an emulsion prepared from it, which was injected under the skin and conjunctiva of another animal, A.

2. The serum of the animal A was inoculated into another individual of the same species.

3. One eye of an animal was badly dairaged and allowed to shrink, then enucleated, and emulsion injected under the skin and conjunctiva.

Results.-1. After three injections, keratitis, iritis, and three nodules of exudate in the anterior chamber were set up. These gradually disappeared and the eye returned to its normal condition. Another injection was made and the other eye was attacked by similar inflammation. No result followed the subconjunctival injectior.

2. Experiment negative.

3. Intense iritis set in after the subconjunctival injection, pointing to the development of an autocytotoxin.

These experiments would show that there is formed in a damaged eye a toxin which is absorbed into the blood stream and gives rise to the formation of antitoxin. If the amount of toxin is small the antitoxin formed can deal with it, but if it is large and the amount of antitoxin formed small an attack of inflammation in the uninjured eye may be caused. If, therefore, an animal be immunized by injecting into it eye emulsion the serum of this animal may be used as a curative agent in cases of sympathetic ophthalmia.

REFERENCES.
1 Sydney.Stephenson: Trans. Ophthalmol. Soc. U.K., vol, xxl, 1. 12 2 Axenfeld : Lancet, ii, 1908.

3 Kornel Scholtz: Arch.f. Augenheilk., September, 1906

4 Romer: 24 Versammiung d. Ophthaimol. Gesellschaft, Heidelberg, 1907.

Snell : British Medical Jocrac, July 4th, 1908

Tovember 18th, 1907 .

8 Darier: La Clin. Ophtalmologique, December 10th, 1910.

9 Alexandroff : La Clin. Ophtalinol., October 10th, 1910.

30 Fromaget: Ann. d'oculestique, t. cxxxviii, p. 182.

11 Darier: Die ophthal. Klinik, 5, June 20th, 1907.
12 Monbouyran: La Clin. Ophtalmol., January 29th, 1808 .

33 Darier: La Clin. Ophtalmol., February 10th, 1907

Geulieres : Die ophthal. Klinil, March 20th, 1908.

17 Burkard: Journ. Amer. Med. Assoc., November 5th

13 Dentschmann: BRITISH MeDICAL JODRNAL, 1908.737

20 Schwalbach: Freien Vereinigung de Clirurgen, Berlin, March,

1508 .

II Von Hippel: Deut. med. Woch., November 27th, 1908.

22 Yapp: Opht halmoscope, $1908,1,1000$.

W. Zimmel mann: Die ophthal. Klinik, 1908, No. 13

ar Aubinean: Aivista Itad de Ottal September

\section{ftemoranta:}

\section{MEDICAL, SURGICAL, OBSTETRICAL.}

CULTIVATION OF TRYPANOSOMA RHODESIENSE. Your reader's might like to hear that T'rypanosoma rhodesiense is cultivable in a modification of Nicolle's medium. The proliferation is very abundant at $25^{\circ}$ to $27^{\circ} \mathrm{C}$., and posterior nuclear forms are fairly numerous. I cannot entirely exclude the possibility of contamination with $T$. levisi, derived from the rats from which the cultures have been made; but Herpetomonas forms have not been seen and the characteristic type of T. lewisi is not present.

$$
\text { Johnston Tropical Laboratory, Cryotherapy Department. }
$$

University of Liverpool.

CASE OF MORPHINE POISONING.

ON February 3rd Dr. Macdonald, of Leven, reported the accidental administration of $\frac{1}{4}$ gr. morphine suppository for a glycerine one to an infant 4 months old, and men tioned the irrigation of the bowel with Condy's fluid as part of the treatment adopted. On February 17th Dr. J. Barker Smith commented on this, and urged the value of potassium permanganate in "breaking up morphine, quinine, cinchona salts, and uric acid.'

My own experience was as follows: I was called on February 28th last at 7 p.m. to see a male infant of 7 months which could not be roused, and "made a strange noise" in breathing. I found the child comatose, with pinpoint pupils, and shallow, strident respiration.

The mother told me she inserted a glycerine suppository at 2 p.m., and sent the child out in its perambulator. It was sound asleep on its return, and later in the evening she became anxious about its breathing, and was not able to rouse it. I found the suppositories were morphine; $1 \mathrm{gr}$. in each, put up in a small tin box by a well-known firm, and identical in general appearance with the glycerine.

I had about $4 \mathrm{gr}$. of potassium permanganate with me, and $I$ injected half of this with some $6 \mathrm{oz}$. of water into the rectum, which $I$ found empty, and the remainder I dissolved in $4 \mathrm{oz}$. of water and siphoned into the stomach. I also gave a subcutaneous strychnine injection, and followed up these measures with oxygen, brief immersions in a warm bath every hour, and continued arifificial respiration.

At midnight the infant had two attacks of thoracic rigidity and quickly increasing cyanosis, like the initial period in the epileptic fit. By $2 \mathrm{a} . \mathrm{m}$. the general condition had distinctly improved, and the stridor was gone; there were signs of recovering reflexes; a little fluid was expelled from the rectum; it moved its arms about and attempted to cry. Thereafter its recovery was so rapid that by 11 a.m. it appeared quite well, with a normal temperature, and looking bright and alert as usual. Crine had been passed freely, the pupils were normal, and the tongue moist.

Throughout the pulse ran about 90 to 100 , and was of good force and volume. It was really weaker twenty-four hour's later, and the extremities were inclined to be cold. I noticed frequent oscillatory movements of the lower jaw during the narcotism. The muscular action was never totally relaxed, for the prehensile grasp of the hands was always evident. The reflex sucking effort was among the earliest signs of improvement. The baby, which is breastfed and just commencing dentition, is very strong and well developed.

Nearly six hours passed between the introduction of the suppository and the beginning of the treatment, and Dr. Macdonald conveys in his note a question as to the relative toxicity of the drug when given per rectum, and, a fortiori, my own case suggests the very same question, apart altogether from the value of antidotal measures.

Hungerford; Berks. Walter Dickson, M.D.Edin.

\section{ANAESTHESIA FOR SUBMUCOUS RESECTION OH} THE SEPTUM.

The method that I have found most useful, after trying packing, injecting, and Freer's methods, only to diseard them as unsatisfactory or dangerous, is to paint the septrun 